\title{
アンダーピニングエ事における杭基礎構造物の 変位予測手法について
}

\author{
市野道明 ${ }^{1} \cdot$ 清水幸範 $^{2} \cdot$ 小泉淳 $^{3}$ \\ ${ }^{1}$ 正会員 工修 佐藤工業株式会社 東京支店副支店長（T160-0023 東京都新宿区西新宿 6-24-1-17F） \\ E-mail:Ichino@satokogyo.co.jp \\ ${ }^{2}$ 正会員 工修 佐藤工業株式会社 東京支店土木部門（T160-0023東京都新宿区西新宿6-24-1-17F） \\ E-mail:Yukinori.Shimizu@satokogyo.co.jp \\ ${ }^{3}$ 正会員 工博 早稲田大学教授 理工学部土木工学科（干169-8555 東京都新宿区大久保 3-4-1) \\ E-mail:koizumi@mn.waseda.ac.jp
}

一般に,アンダーピニングにおける構造物の変位挙動の予測は, 単杭基礎の沈下計算に基づき行われ ている.しかしこれらの場合，その予測值と実測值にはあまり良い一致が見られない実状にある.これ は, 既設杭と新設杭の挙動に伴う相互の影響を無視していることによる. 本研究はこの既設杭と新設杭 との相互作用をばねで評価し, アンダーピニング時の挙動を説明できる解析モテルを提案するとともに, 現場計測結果との比較から本解析モデルの妥当性を明らかにするものである.

Key Words : underpinning, behavior forecasting analysis, interaction of piles, complex spring model, preceding stress introduction

\section{1.はじめに}

東京などの都市部は，急激な経済成長に伴う過密 化や集積化が激しい. その地下も例外ではなく, 道 路下においては鉄道, 下水道, 電力, 通信などの施 設が輻輳しており, 中浅程度までの地下の領域はす でに満杯の状態になっている.このような状況から， 新たな鉄道などの地下施設の建設は, 残された空間 である大深度の領域や民有地下の領域で行われるケ 一スが増えてきている ${ }^{1)}$.

トンネルの建設には, 地上周辺部および地下の既 存施設に与える影響が小さいことから, シールドエ 法を採用する例が多い. しかしながら，民有地には 高層ビル群が, また道路上には高架鉄道, 高架道路 などの橋脚が位置しており, これらの下をシールド が掘進する場合にその基礎杭が支障となる.このた め既設構造物の一部あるいは全部を新たな基礎に受 替えるアンダーピニングが必要となる場合が多い.

このような特殊な施工条件の増加に伴い, アンダ
一ピニングはその件数が飛躍的に増加するとともに 大規模化してきている ${ }^{2)}$. アンダーピニングにおい ては, 既設建物の健全性の確保, 応力導入（プレロ 一ド）時の受替荷重の評価などの観点から, 既設建 物や受替構造物の変位挙動を予測することは重要な 課題である.

現状の変位挙動の予測には杭基礎の設計手法を 用いて, 既設建物や受替構造物の鉛直変位量を算出 するのが一般的である ${ }^{3), 4), 5)}$. しかしこれらの場合, 予測值は実測值の数倍程度大きく算出されることが 多く,十分にその挙動を評価しているとは言い難い. このため図-1に示すように, 地盤変形係数などを補 正して応力導入時の実測変位に適合させるのが一般 的であり，この補正值を用いて最終的な建物の変位 量, 受替構造物の沈下量を推定しているのが実状で ある. したがって, 受替荷重の評価が十分でないこ とから, 初期の応力導入時の施工管理では, 建物の 健全性は計測工による事後判定とならざるを得ない など合理性に欠ける. 


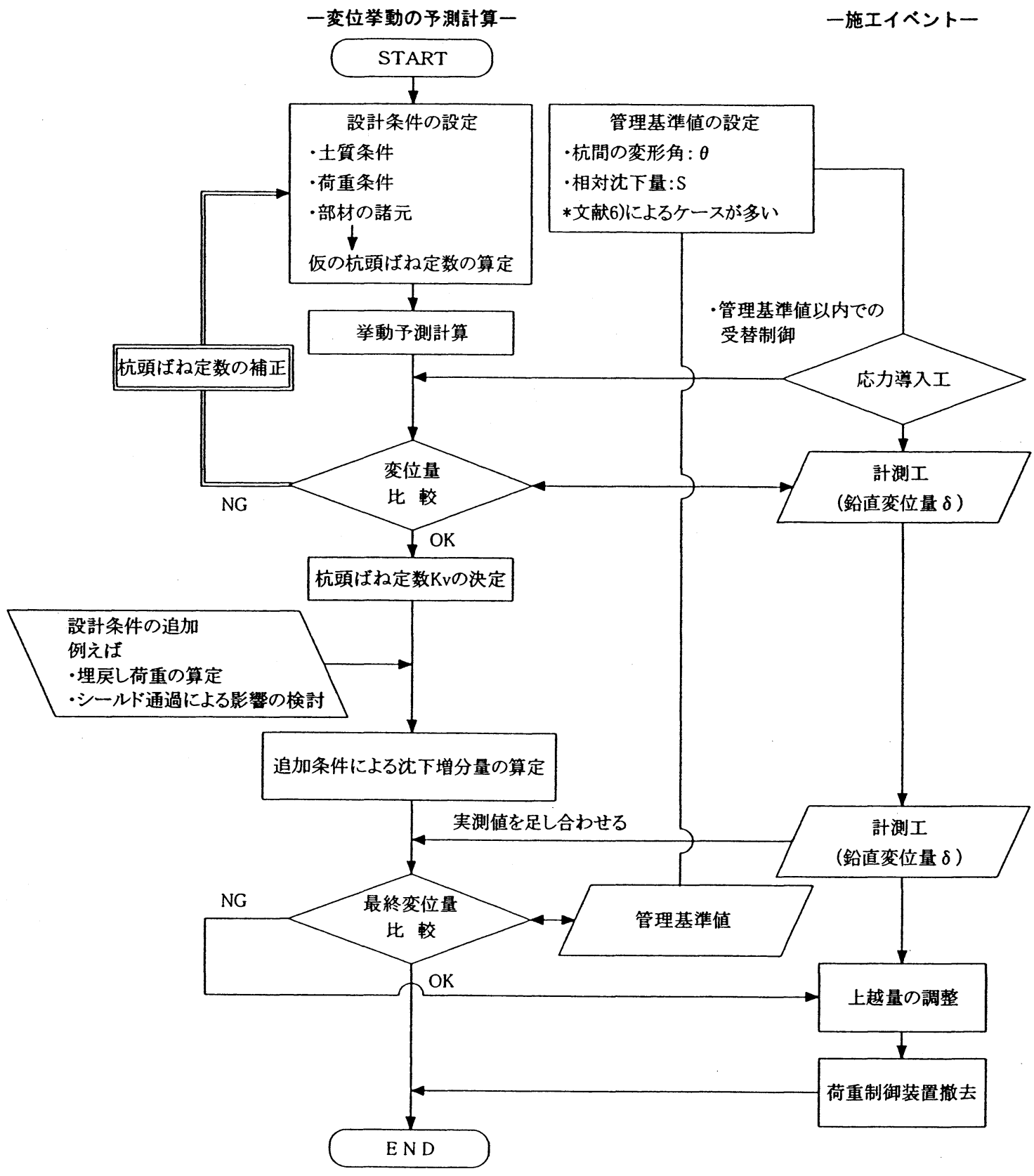

図-1一般的な挙動予測のフロー

予測值と実測值の不一致は, 既設杭と新設杭の挙 動に伴う相互干渉を考慮していないことによると考 えられる，既設杭の上向きへの力は，周辺地盤を介 して新設杭に影響を与えるためその沈下の一部を相 殺する現象が起き, 結果として実測值は予測值より はるかに小さくなるものと推察される.

この既設杭と新設杭の相互作用については猪瀬
らの研究 ${ }^{6}$ がある.これは対称性の高い受替構造を 対象として, 受替荷重は杭のみを介して地盤に伝わ るという条件のもとで，その相互作用を軸対称有限 要素法により求めた変位伝達関数を用いて評価する ものである. しかしながら, 非対称の受替構造で, かつ施工手順として受替版下の地盤を残した状態で 応力導入をする場合には，この方法を適用するのは 


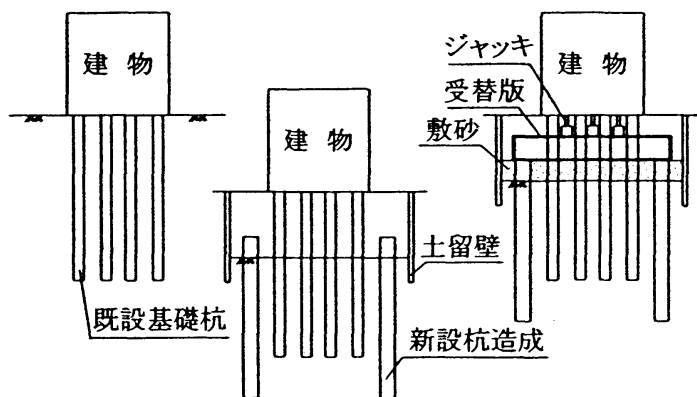

(1)現況

(2) 掘削,新設杭

(3)敷砂埋戻し,受替版構築

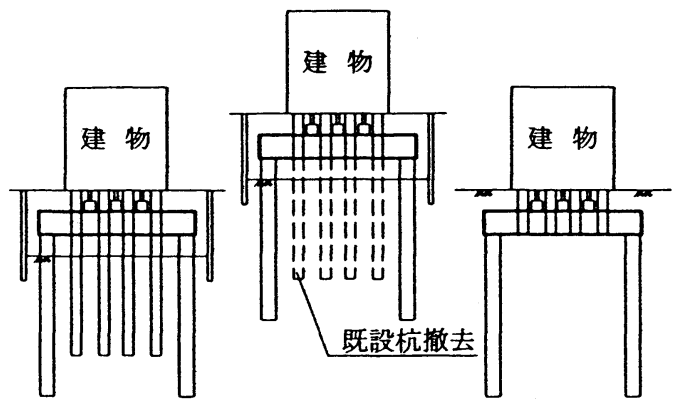

(6)埋戻し復旧

a）一般的な場合（先行掘削）
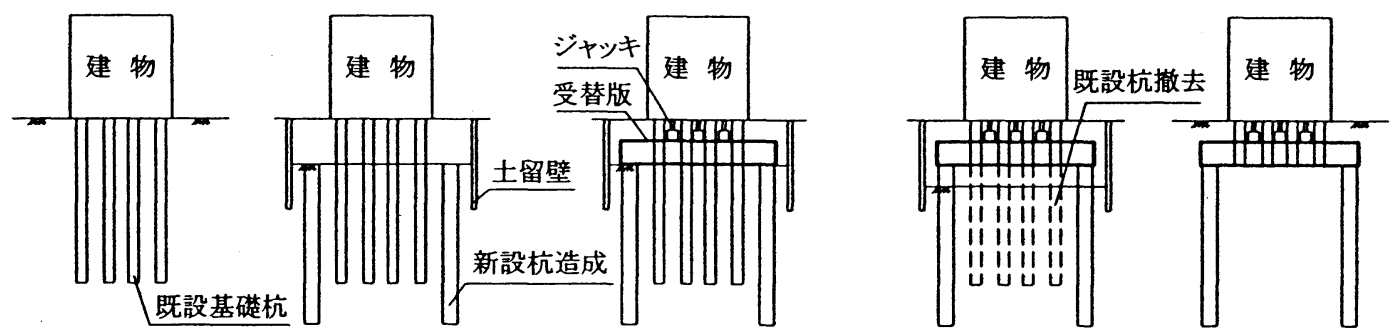

(1) 現況

(2) 掘削,新設杭

(3)受替版構築,応力導入 (4)受替版下掘削,既設杭撒去 (5) 埋戻し復旧

b）工期を短縮する場合（先行応力導入）

図-2 アンダーピニングの施工手順の比較

困難である. しかし，このような複雑な施工条件下 のアンダーピニングは, 今後も増えるものと推察さ れる。

本研究はより汎用性を有し精度の高いアンダー ピニングにおける構造物の変位挙動の予測モデルを 提案するものであり,この挙動予測モデルは, 様々 な施工条件下のアンダーピニングにおいて受替初期 の建物の健全性, 受替荷重, 最終的な建物と受替構 造物の健全性の評価を可能にするものと考えている. また, 本研究では現場計測結果との比較から本予測 モデルの妥当性を検証している.

\section{2. 挙動予測の対象となるアンダーピニングの 概要}

本研究で取り扱うアンダーピニングは, 工期短縮 の目的からその施工手順において従来のものと異な

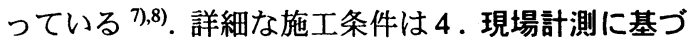
く複合ばねモデルの評価で述べるが，ここでは一般
的な手法に基づくアンダーピニングの施工手順と本 研究の対象としたそれとを比較することにより，ア ンダーピニングの状況を明確にし変位挙動の予測モ デル導入の助けとする.

\section{（1）一般的な手法を本研究の対象としたアンダー ピニングに適用する際の問題点}

下受け梁方式によるアンダーピニングは, 応力導 入に先行して受替版下の地盤を掘削するケースが多 い.これは受替版の自重による変形, 受替版下の地 盤反力, および掘削に伴う地盤のリバウンドなどの 変位挙動の予測や受替えの制御を複雑にする要因を 回避するためである（以降これを先行掘削と呼ぶ）.

しかしながら, 本研究の対象としたアンダーピニ ング工事（以降これを本工事と呼ぶ）にこの先行掘 削型のアンダーピニングを適用する場合, 新設杭の 施工に必要な深さまで掘削した後に, 増し打ち分を 考慮した新設杭の造成と埋め戻しおよび受替版の構 築を行う必要がある. その後, 敷き砂の再掘削を経 て応力導入を実施する. このため杭の增し打ち, 敷 
き砂の埋め戻しと掘削の 3 つの工程が手戻りとなり 不経済な工程になる(図-2-a)).

またアンダーピニングする建物の下は, 既設と新 設の杭が林立している.このため受替版下の再掘削 は狭险な空間での施工となり, 大型の重機などが搬 入できず施工能率が低下せざるを得ない.

\section{（2）工期短縮を考慮したアンダーピニング}

（1）で述べたことから，本工事では受替版の下端 を一次床付け盤とし，ここから新設杭の造成および 受替版の構築を行い, 受替版下の地盤を残した状態 で応力導入を行うことにした（図-2-b)).

一次床付け盤からの空頭で施工可能な低空頭式拡 底機の建築評定を新たに取得することで, 余分な 3 つの工程が省略できる．また受替版下の掘削に先行 して応力導入を行うため（以降これを先行応力導入 と呼ぶ)，既設杭の撤去と受替版下の掘削が併行して 作業できる.これにより大型重機の搬入スペースが 確保でき，進渉率の良い工程となる．本工事ではこ れらの方法を採用することにより，およそ 2 ケ月の 工期短縮を実現している.

計測工や受替制御の技術進歩を積極的に利用し た本工事の方法は，狭险な空間におけるアンダーピ ニングの合理的な手法の一つであると考えている.

\section{3. 複合ばねモデルの導入}

本節では変位挙動の予測に用いる複合ばねモデ ルの概念と, それを構成する各ばねのばね定数の算 定方法について述べる.

複合ばねモデルは，前述の既設杭と新設杭との相 互作用を考慮したものであり, 図-3に示すような構 造を考えた. すなわち, 受替版を骨組構造でモデル 化し，これがばねにより支持されているものとする. 複合ばねのばね定数 $K v, K r$ は次式で表される.

$$
\begin{gathered}
K v=\frac{k_{p} \cdot k_{v}}{k_{p}+k_{v}}+k_{s v}+k_{i n t} \\
K r=K v \cdot I y
\end{gathered}
$$

ここに

$K v:$ 杭の鈶直方向複合ばねのばね定数 $(\mathrm{kN} / \mathrm{m})$

$K r:$ 杭の回転方向複合ばねのばね定数 $(\mathrm{kN} \cdot \mathrm{m} / \mathrm{rad})$

$k_{p}$ : 杭の弾性変形を評価するばねのばね定数 $(\mathrm{kN} / \mathrm{m})$

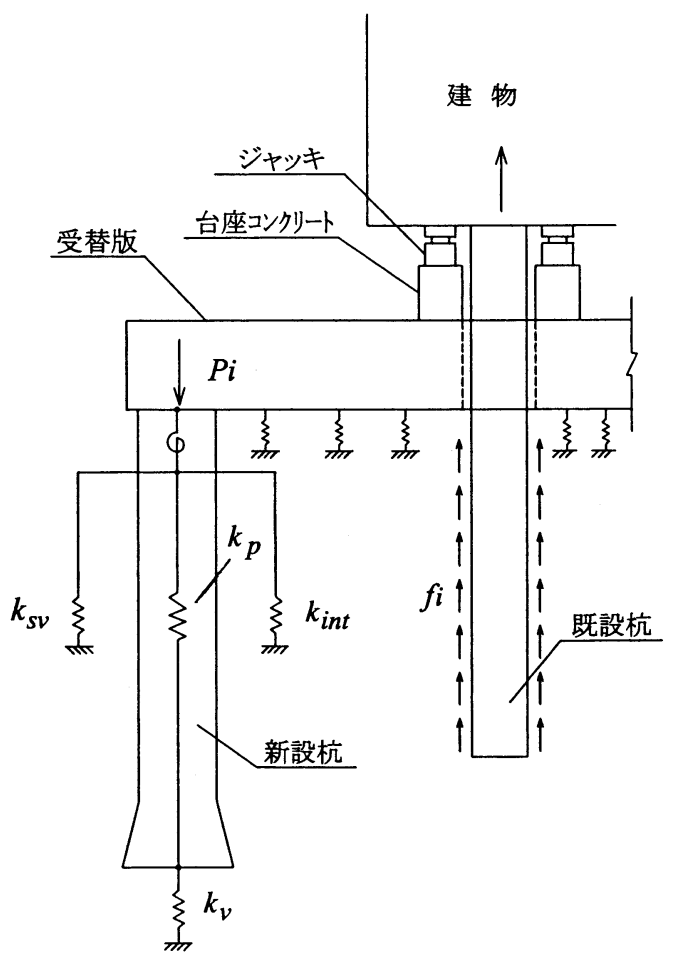

図-3 複合ばねモテルの概要

$k_{v}$ :杭先端の地盤反力を評価するばねのばね定数 $(\mathrm{kN} / \mathrm{m})$

$k_{s v}$ : 杭周面の鉛直方向せん断地盤反力を評価す るばねのばね定数 $(\mathrm{kN} / \mathrm{m})$

$k_{\text {int }}$ : 杭周面に作用する既設杭と新設杭との相互 作用を評価するばねのばね定数 $(\mathrm{kN} / \mathrm{m})$

$I_{y}: \mathrm{y}$ 軸 ( $\mathrm{y}$ 軸は杭軸直角方向のうち, 杭群の回 転を考慮すべき軸) 回りの杭群の 2 次モーメ ント $\left(\mathrm{m}^{2}\right)$

である.

式(1a)が本研究で提案する複合ばねのばね定数で あり，杭の鈶直方向のばねを総合的に評価するもの である. すなわち, 杭の軸芯に作用する $k_{p}$ と $k_{v}$ と を直列に連結させた鉛直方向ばねに杭周面に作用す る $k_{s v}$ と $k_{\text {int }}$ を並列に連結したものである. また, アンダーピニング時の受替荷重の荷重度は, 杭の許 容支持力以下であるため, 杭の荷重-沈下曲線は弾性 範囲内にあると思われる ${ }^{9}$. このことから，ばねの ばね定数の算定においては, 杭本体やその周辺の地 盤が弾性範囲内の挙動を示すものと仮定した. 以下 に複合ばねを構成する各ばねのばね定数を具体的に 算定する方法を述べる. なお, 式(1b)は基礎の構造 に応じて考慮すべきばね定数であり，これについて 


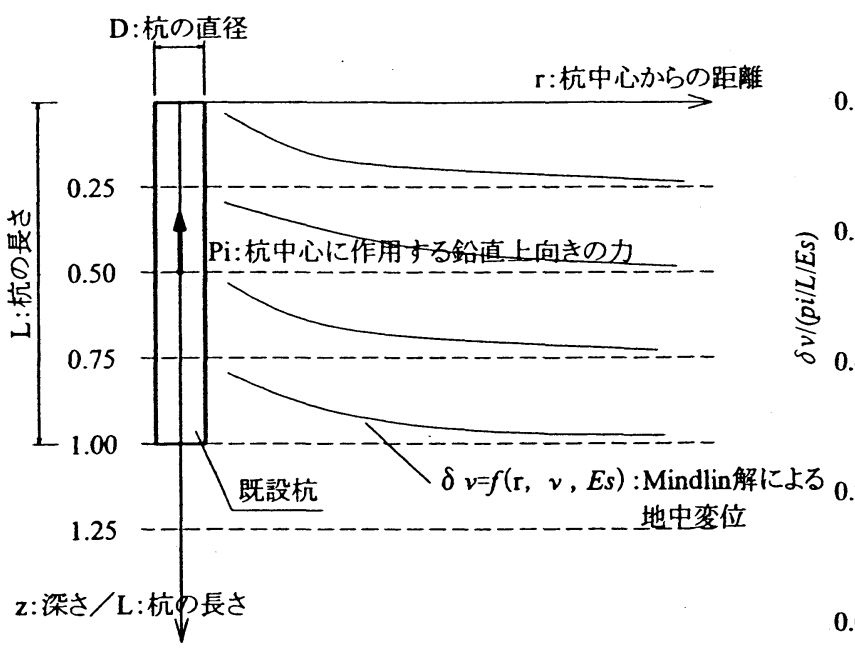

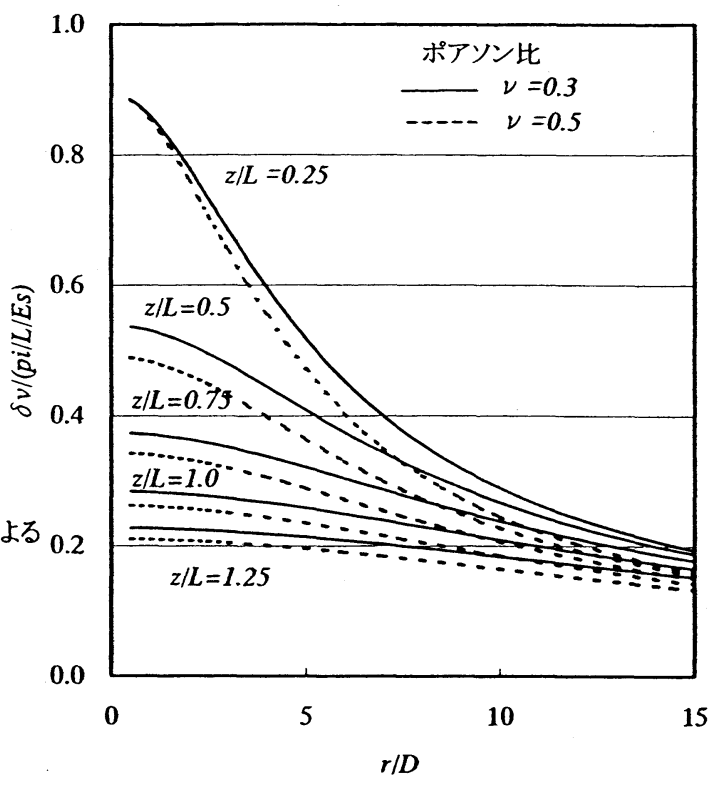

図-4 Mindlin による変位解と地盤特性の関係

は文献 10)を参照されたい，

（1）杭の弾性変形, 杭先端の地盤反力および杭周面 の地盤反力を評価するばねのばね定数の算定

杭の弾性変形を考慮するばねのばね定数 $k_{p}$ は次 式により与えられる.

$$
k_{p}=\frac{E_{p} \cdot A_{p}}{L_{p}}
$$

ここに

$E_{p}:$ 新設杭の弾性係数 $\left(\mathrm{kN} / \mathrm{m}^{2}\right)$

$A_{p}:$ 新設杭の軸部の断面積 $\left(\mathrm{m}^{2}\right)$

$L_{p}:$ 新設杭の長さ $(\mathrm{m})$

である.

杭先端の地盤反力を評価するばねのばね定数 $k_{v}$ は次式により与える. なお, 地盤反力係数の推定に は文献 10)に示される方法を用いている. また地盤 の変形係数は孔内水平載荷試験と室内土質試験の結 果から決定している.

$$
\begin{gathered}
k_{v}=k_{v}^{*} \cdot A_{p v} \\
k_{v}^{*}=0.2 \cdot \alpha \cdot E_{s} D^{-3 / 4}
\end{gathered}
$$

ここに,

$k_{v}^{*}:$ 杭先端の鉛直方向地盤反力係数 $\left(\mathrm{kN} / \mathrm{m}^{3}\right)$

$A_{p v}:$ 杭先端の断面積 $\left(\mathrm{m}^{2}\right)$

$\alpha: E_{S}$ の算定方法および荷重条件に対する補正

\section{係数}

$E_{S}:$ 地盤の変形係数 $\left(\mathrm{kN} / \mathrm{m}^{2}\right)$

$D:$ 杭先端の直径(m) である.

杭周面の鈶直方向のせん断地盤反力を評価する ばねのばね定数 $k_{s v}$ は次式により算定する.

$$
\begin{gathered}
k_{s v}=\sum_{i=1}^{n} k_{s v i}^{*} \cdot U_{i} \\
k_{s v i}^{*}=0.03 \cdot \alpha \cdot E_{s} \cdot D^{-3 / 4}
\end{gathered}
$$

ここに,

$k_{s v i}^{*}$ : 地層ごとの杭周面鉛直方向せん断地盤反力 係数 $\left(\mathrm{kN} / \mathrm{m}^{3}\right)$

$U_{i}:$ 各地層に位置する杭の周面積 $\left(\mathrm{m}^{2}\right)$

$n:$ 地層の数

である.

\section{（2）杭と杭との相互作用を評価するばねのばね定 数の算定}

応力導入時に, 既設杭は建物の挙動に伴い鈶直上 向きに変位し, 新設杭の沈下量を相殺する. すなわ ち, 既設杭の周面から周辺地盤に伝わる荷重は, 地 盤をせん断変形させることにより，新設杭を仮の単 純沈下位置から相対的に隆起させるものと考えられ る. 本研究ではこのような地盤を介する杭と杭との 相互作用を, Mindlin 解を用いたばねにより評価した. 相互作用に関する研究は，群杭基礎の分野で見ら 


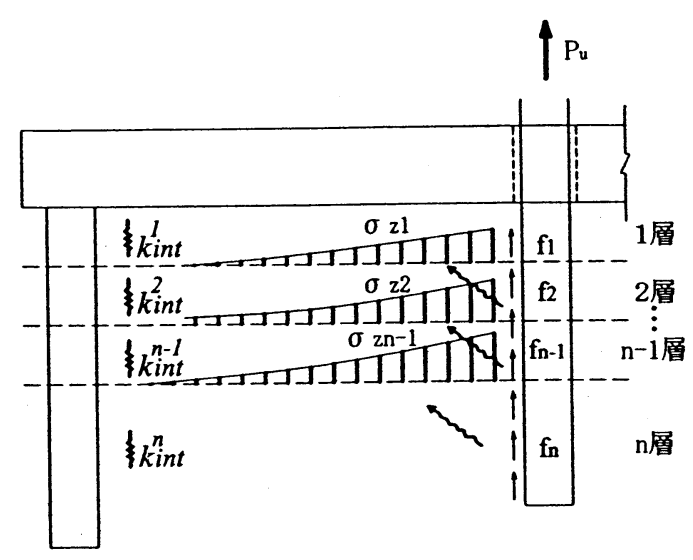

図-5＼cjkstart互層地盤における対応

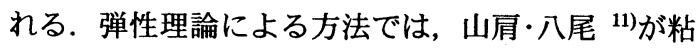
土地盤中の摩擦群杭基礎の沈下解析に関して, Mindlin 解の適合性を示している. 山本ら ${ }^{12)}$ は変位 影響係数に関して，地盤と杭との剛性の違いによる 影響は, 加力点近傍のみであることを示している. これらに共通している事象は，任意点の変位を求め る変位影響係数により相互作用を評価することであ り,ばねによる評価は見受けられない.

一方, Mindlin の解は半無限弾性地盤中の集中荷 重によるものであるため, その適用においては注意 が必要である.

まず地盤の変形特性に関する問題は, Mindlin 解 がポアソン比を含んでいるため, この影響を検討す る必要がある. 平山 ${ }^{13)}$ は応力解に関してポアソン比 の影響はさほど大きくないことを明らかにしている. ここでは変位解における地盤特性の影響について考 察する.

図-4 はポアソン比をパラメーターとして地中の 変位分布を示したものである. 図中, $\delta_{v}$ は Mindlin 解により求まる地中の鉛直方向の変位, $P_{i}$ は杭の中 心に作用する荷重, $E_{s}$ は地盤の変形係数, $z$ は地中 の深さ, $L$ は杭の長さ, $r$ は杭の中心からの水平距離, $D$ は杭の直径である. この図から, 変位解における ポアソン比の影響は, $r / D>10$ 程度の領域において もさほど小さくならないことがわかる.このことか ら, アンダーピニング部の周辺地盤が複雑な互層地 盤の場合に, 各地層ごとの変形特性を用いて相互作 用ばねのばね定数 $k_{i n t}^{n-1}$ を評価するのがよく, 図-5 に示すような方法を用いてそれを算出することとし た. すなわち, 分散荷重による各層境の地中応力 $\sigma_{z i}$ を求め, これと周辺摩擦応力 $f_{i}$ による弾性解の和か

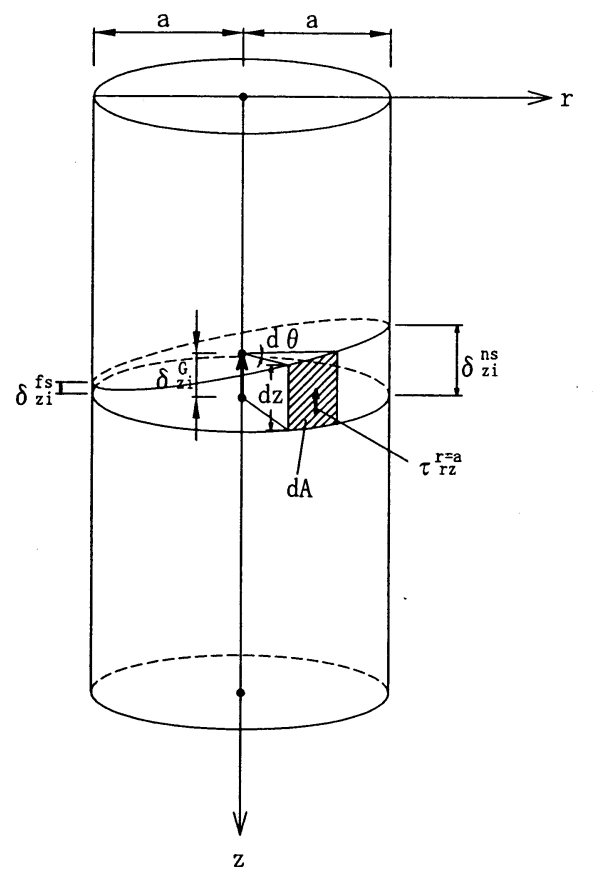

図-6 Mindlin 解による相互作用ばねのばね定数の 算定

ら当該地層の相互作用ばねのばね定数が評価できる という考えである.

$$
k_{\text {int }}^{n-1}=k_{\text {int }}^{n-1}\left(\sigma_{z n-1}\right)+k_{\text {int }}^{n-1}\left(f_{n-1}\right)
$$

ここに,

$k_{i n t}^{n-1}: n-1$ 層の相互作用ばねのばね定数

$k_{i n t}^{n-1}\left(\sigma_{z n-1}\right): n-1$ 層の地盤内応力の影響による 相互作用ばねのばね定数

$k_{\text {int }}^{n-1}\left(f_{n-1}\right): n-1$ 首の杭の周辺摩擦応力の影響に である. よる相互作用ばねのばね定数

次に集中荷重に関する問題であるが，これは集中 荷重をそれと等価な分散荷重に置換することで対応 できる. しかしながらその計算は繁雑になるので, 載荷点とある程度の離隔を有する場合は, 集中荷重 から直接相互作用の影響を評価しても良いと思われ る. なお, この集中荷重と分散荷重の違いによる地 盤内応力ついては多くの研究 ${ }^{13), 14) か ゙ あ り, ~ そ れ ら か ゙ ~}$ 参考となる.

以上のことから, 既設杭と新設杭との相互作用を 評価するばねのばね定数 $k_{\text {int }}$ は, 图-6 を参考にして 次式から算定することとした. 


$$
\begin{gathered}
a v e\left(\delta_{z i}^{n s}, \delta_{z i}^{f s}\right)=\delta_{z i}^{G} \\
k_{\text {int }}=\sum_{i=1}^{n}\left(\int_{0}^{l} \frac{\int_{0}^{2 \pi} \tau_{r z i}^{r=a} \cdot d A d \theta \cdot I_{p}}{\delta_{z i}^{G}} d z\right)
\end{gathered}
$$

ここに

$\tau_{r z i}:$ Mindlin の第 1 解よる応力解 $\left(\mathrm{kN} / \mathrm{m}^{2}\right)$

$\delta_{z i}:$ Mindlin の第 1 解よる変位解 $(\mathrm{m})$

$I_{p}$ : 杭の形状による影響を表す係数（ここでは 1.0 とした)

$n$ : 対象とした新設杭に影響を与える既設杭の本 数

$l:$ 地盤中にある新設杭の長さ $(\mathrm{m})$

$a:$ 新設杭の半径(m)

である.

\section{（3）受替版下の地盤反力を評価するばねのばね定 数の算定}

受替版下の地盤ばねのばね定数 $k_{s}$ は次式により 算定する. なお，地盤反力係数の推定には文献 10) の方法を用いている.

$$
\begin{gathered}
k_{s}=A_{v 0} \cdot k_{s}^{*} \\
k_{s}^{*}=k_{s 0}^{*}\left(\frac{B_{s}}{0.3}\right)^{-3 / 4}
\end{gathered}
$$

ここに,

$A_{v 0}:$ 受替版底部の単位面積 $\left(\mathrm{m}^{2}\right)$

$k_{s}^{*}:$ 受替版底部の鉛直方向の地盤反力係数 $\left(\mathrm{kN} / \mathrm{m}^{3}\right)$

$k_{s 0}^{*}$ : 土質試験より求めた変形係数より推定する 地盤反力係数 $\left(\mathrm{kN} / \mathrm{m}^{3}\right)$

$$
k_{s 0}^{*}=\frac{1}{0.3} \alpha \cdot E_{s}
$$

$\alpha: E_{s}$ の算定方法および荷重条件に対する補正 係数

$E_{s}:$ 地盤の変形係数 $\left(\mathrm{kN} / \mathrm{m}^{2}\right)$

$B_{s}:$ 基礎の換算載荷幅 $(\mathrm{m})$

である.

\section{（4） 既設建物の挙動を評価するばねのばね定数の 算定}

一般にアンダーピニングは, 建物の一部分を多点 支持により受替えることが多い. このため, 建物を 3 次元のラーメン構造などで評価したモデルに荷重 または変位を作用させ, 任意点の変位量を算出する のが望ましいと考える. しかしながら，建物の剛性 は地中梁や基礎スラブの剛性だけではなく，上部の

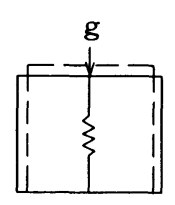

状態 a)

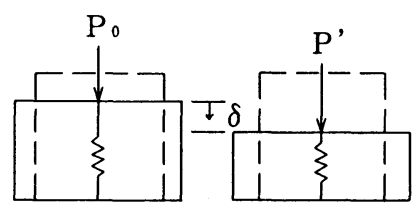

状態 b)
状態 c)

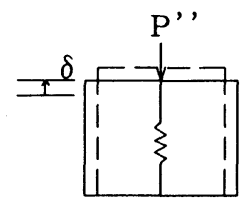

状態 d)
图-7圧縮領域において地盤が主衝的挙動を示すと きの地盤反力を評価するばね

梁, 壁, 柱などの剛性の影響を受けているため, 構 造の適正なモデル化は困難である.

これらのことから，建物の変位は次式により算定 することとした.

$$
\begin{gathered}
\delta_{i}=\frac{P_{i}}{K_{v}^{u}} \\
K_{v}^{u}=\frac{k_{p} \cdot k_{v t}}{k_{p}+k_{v t}}+k_{s v}+k_{i n t}^{u}
\end{gathered}
$$

ここに

$\delta_{i}:$ 既設杭の杭頭の鉛直変位 $(\mathrm{m})$

$P_{i}:$ 応力導入荷重 $(\mathrm{kN})$

$K_{v}^{u}$ : 既設杭の挙動を評価する鉛直方向の複合ば ねのばね定数 $(\mathrm{kN} / \mathrm{m})$

である.

式(9a)により各既設杭の杭頭の鉛直変位を算出し これを建物の当該点の変位とした. また式(9b)に示 した既設杭の変位を算出するときの鉛直方向の複合 ばねのばね定数 $K_{v}^{u}$ が式(1a)に示す複合ばねのばね 定数 $K v$ と異なるのは, 右辺第 1 項中の $k_{v t}$ と右辺第 3 項の $k_{\text {int }}^{u}$ の 2 か所である. 次に, これに関して考 察を加える.

a）杭先端部付近の地盤の主僖的な挙動を評価する ばね

シールドトンネル覆工の設計を例とした木村ら の研究 ${ }^{15)}$ によれば, 覆工がトンネル外側に変形し地 盤が受㗢的挙動を示す場合と，覆工がトンネル内空 側に変形し地盤が主働的挙動を示す場合とでは，そ れぞれの変形特性が異なるとしている.これらの挙 動を弾性ばねでモテル化する場合, 主働的挙動を評 価するばねのばね定数は, 受㗢的挙動を評価するそ 
表-1 建物重量と受替荷重

\begin{tabular}{|c|c|c|c|c|}
\hline 建物種類 & 構造形式 & $\begin{array}{c}\text { 建物重量 } \\
(\mathrm{MN})\end{array}$ & $\begin{array}{c}\text { 受替重量 } \\
(\mathrm{MN})\end{array}$ & $\begin{array}{c}\text { 割合 } \\
(\%)\end{array}$ \\
\hline $\begin{array}{c}\text { JR 社宅 } \\
6 \text { 号棟 }\end{array}$ & $\begin{array}{c}\mathrm{RC} \text { 造 } \\
12 \mathrm{~F}\end{array}$ & 167 & 62.3 & 37.3 \\
\hline $\begin{array}{c}\text { JR 社宅 } \\
3 \text { 号棟 }\end{array}$ & $\begin{array}{c}\mathrm{RC} \text { 造 } \\
12 \mathrm{~F}\end{array}$ & 167 & 36 & 21.6 \\
\hline $\begin{array}{c}\text { 品川区 } \\
\text { 防災セン夕- }\end{array}$ & $\begin{array}{c}\mathrm{RC} \text { 造 } \\
8 \mathrm{~F}\end{array}$ & 284 & 54.5 & 19.2 \\
\hline 合計 & - & 618 & 152.8 & - \\
\hline
\end{tabular}

れの半分程度であることを模型実験から求めている. 図-7 はその概念を模式的に表した図であり, 状態 a) は土柱に土の重量のみが作用している状態である.

状態 b)は, 建物荷重などを受けて土柱が縮んでいる 状態であり, 受替える前の状態がこれにあたる. 状 態 c)は, 状態 b)に新たな荷重が作用して土柱がさら に圧縮される状態であり, 新設杭の先端部における 地盤の受働的な挙動を表している. 状態 d)は, 状態 b)からある程度の荷重が減少して土柱が伸張する状 態であり, 既設杭の先端部における地盤の主働的な 挙動を表している.

このことから, 既設杭先端の地盤の主働的な挙動 を評価するばねのばね定数 $k_{v t}$ は次式により算定す ることとした。

$$
k_{v t}=\frac{1}{2} k_{v}
$$

ここに,

$k_{v t}$ : 圧縮領域において地盤が主働的挙動を示す ときの地盤反力を評価するばねのばね定数 $(\mathrm{kN} / \mathrm{m})$

$k_{v}$ : 地盤が受働的挙動を示すときの地盤反力を評 価するばねのばね定数 $(\mathrm{kN} / \mathrm{m})$ である.

\section{b）受替版と既設杭との相互作用を評価するばね}

既設杭における相互作用は, 既設杭と新設杭との 間，および既設杭と受替版との間に生じる. 荷重作 用点との距離を考えれば後者の方が支配的であるた め,ここでは既設杭と受替版との間の相互作用を評 価する.

この相互作用を評価するばねのばね定数 $k_{i n t}^{u}$ は, 次式により算定する. なお, ばね定数の算定の概念 は式(6)と同様であり, 地中の応力伝播を Boussinesq 解により評価する. また作用荷重は, ジャッキ軸芯
表-2 受替工の概要

単位 : 本

\begin{tabular}{|c|c|c|c|c|c|}
\hline \multirow{2}{*}{ 建物種類 } & \multicolumn{3}{|c|}{ 撤去杭 } & \multicolumn{2}{c|}{ 新設杭 } \\
\cline { 2 - 6 } & 800 & 1,000 & 2,000 & 2,000 & 2,200 \\
$(\mathrm{~mm})$ & $(\mathrm{mm})$ & $(\mathrm{mm})$ & $\begin{array}{c}2, \mathrm{~mm}) \\
(\mathrm{mm})\end{array}$ \\
\hline $\begin{array}{c}\text { JR 社宅 } \\
6 \text { 号棟 }\end{array}$ & 6 & 22 & - & 13 & - \\
\hline $\begin{array}{c}\text { JR 社宅 } \\
3 \text { 号棟 }\end{array}$ & 4 & 11 & - & 8 & - \\
\hline $\begin{array}{c}\text { 品川区 } \\
\text { 防災センタ- }\end{array}$ & - & 3 & 7 & - & 16 \\
\hline
\end{tabular}

上に作用する受替荷重とした.

$$
\operatorname{ave}\left(\delta_{z i}^{n s}, \delta_{z i}^{f s}\right)=\delta_{z i}^{G}
$$

$$
k_{i n t}^{u}=\sum_{i=1}^{n}\left(\int_{0}^{l} \frac{\int_{0}^{2 \pi} \tau_{r z i}^{r=a} \cdot d A d \theta \cdot I_{p}}{\delta_{z i}^{G}} d z\right)
$$

ここに，

$\tau_{r z i}$ : Boussinesq による応力解 $\left(\mathrm{kN} / \mathrm{m}^{2}\right)$

$\delta_{z i}:$ Boussinesq よる変位解(m)

$I_{p}$ : 杭の形状による影響を表す係数（ここでは 1.0 とした)

$n$ : 対象とした既設杭に影響を与えるジャッキ受 け台座の数

$l:$ 地盤中の杭の長さ $(\mathrm{m})$

$a:$ 新設杭の半径 $(\mathrm{m})$

である.

\section{4. 現場計測に基づく複合ばねモデルの評価}

\section{(1) アンダーピニングエ事の概要 16),17)}

本研究の対象とした工事は, 臨海副都心線 2 期工 事の第 1 広町トンネル工区における建物 3 棟のアン ダーピニングである. 大井町駅と大崎駅との間に位 置する第 1 広町トンネルは, シールド工法により建 設される外径 $7,100 \mathrm{~mm}$ の鉄道単線断面トンネルで ある.この路線上には, RC 造 12 階建の JR 広町社 宅 2 棟之, $\mathrm{RC}$ 造 8 階建の品川区防災センターの計 3 棟の建物が位置し, それらの建物の基礎杭の一部 がトンネル掘削の支障となるためアンダーピニング を実施した。

受替えは下受け梁方式とし, 建物の総重量 618MN の内 152.8MN を受替えるものである（表-1）. また 


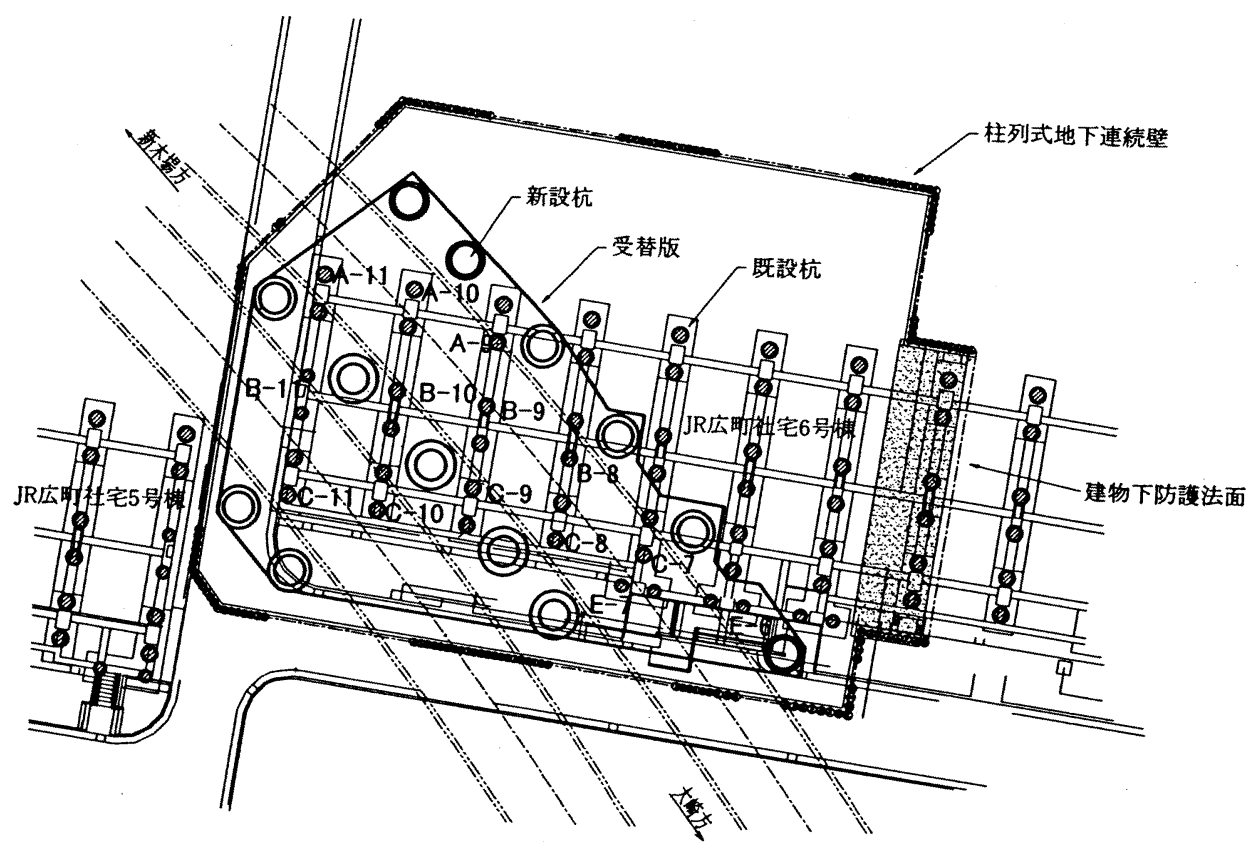

图-8 JR 広町社宅 6 号棟における受替状況

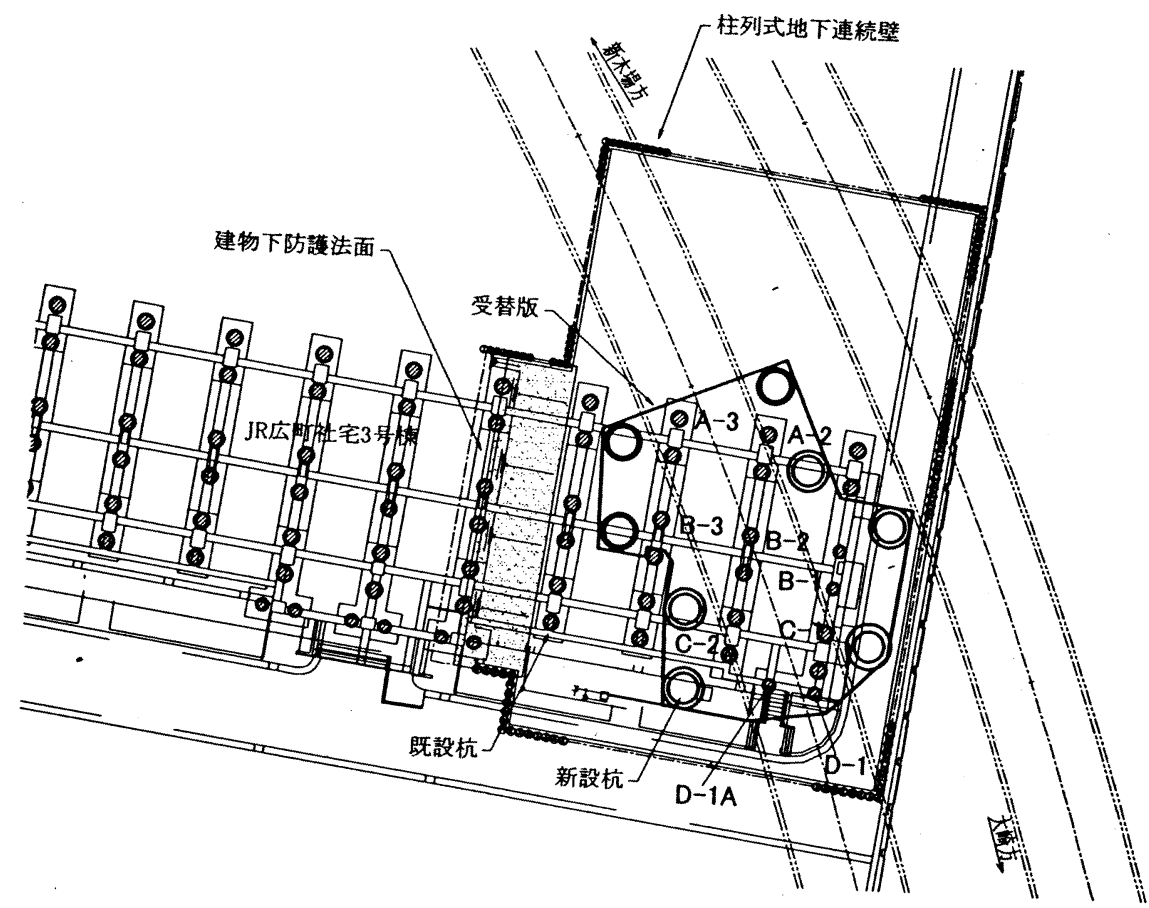

图-9 JR 広町社宅 3 号棟における受替状況

3 棟すべてにおいて，前述したように，工期短縮を 目的とした先行応力導入（受替版下の地盤を残した 状態でプレロードを行う）を実施している.

土質は地表から $1.8 \mathrm{~m}$ 程度まで埋土層が分布して
おり, その下に $\mathrm{N}$ 值 30 程度の武蔵野喽層が $3.4 \mathrm{~m}$ 程 度の厚さで分布している. さらに $\mathrm{N}$ 值 10 程度の東 京粘土層 (一部東京砂層が介在) が $16 \mathrm{~m}$ 程度分布し, その下に周辺構造物の支持層である $\mathrm{N}$ 值 50 以上の 


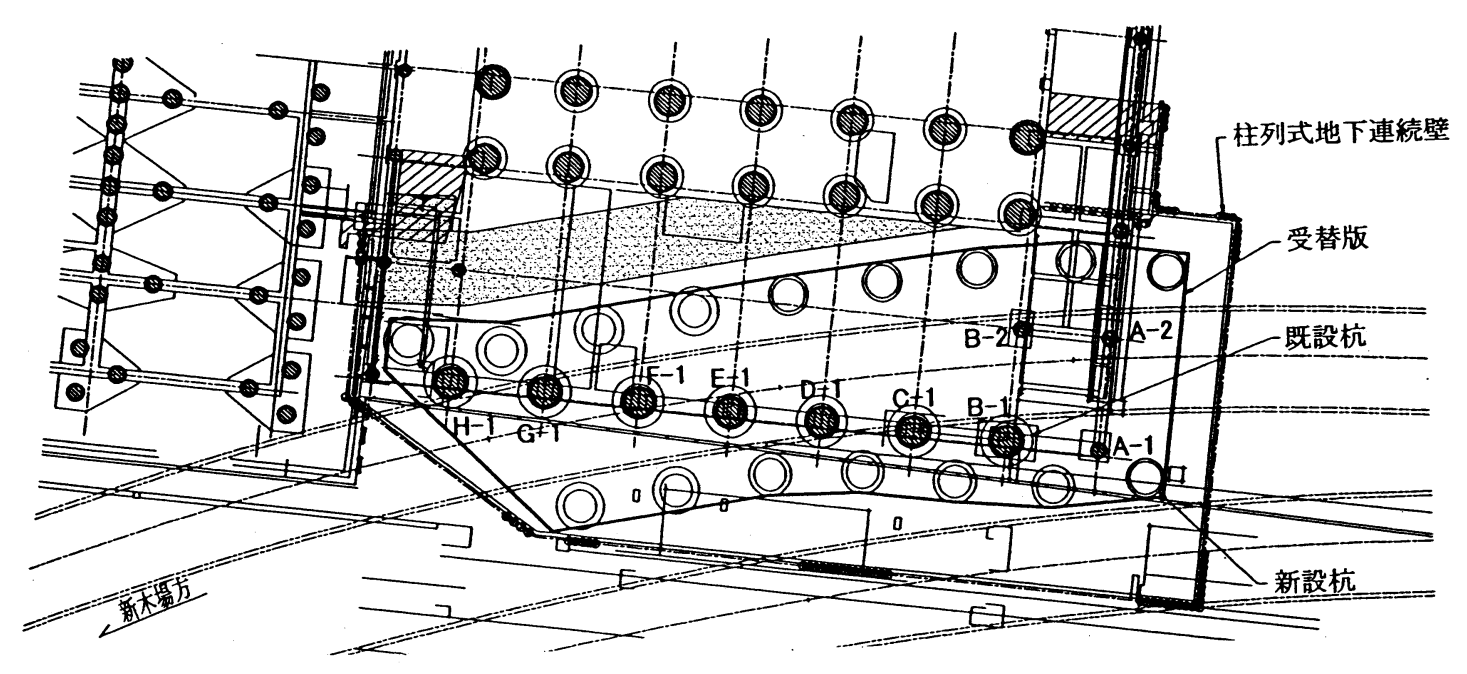

図-10 品川区防災センターにおける受替状況
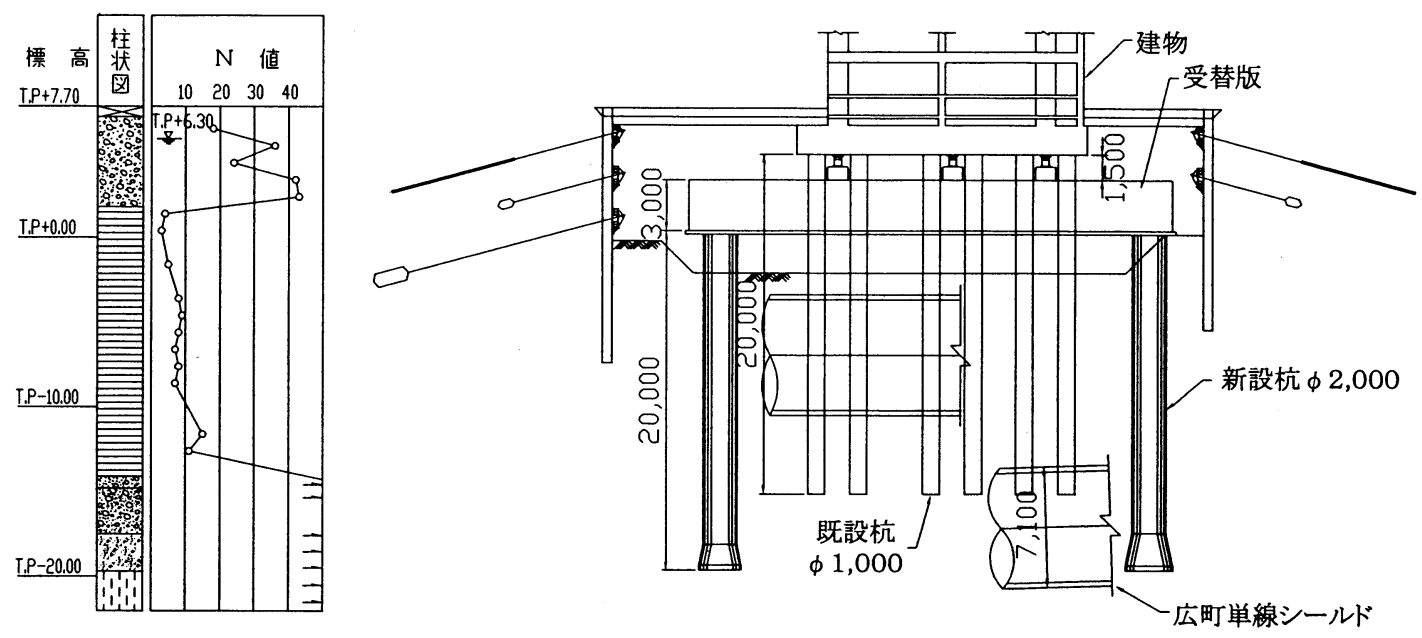

図-11 受替状況の断面

東京磁層が分布している．この東京碟層には水が豊 富に存在する. 透水係数は $\mathrm{k}=10^{-1} \sim 10^{-2} \mathrm{~cm} / \mathrm{sec}$ の範囲 にあり, かつ $20 \mathrm{~m}$ 程度の被圧水頭を持っている.こ のため, 受替杭の造成および既設杭撤去の支障とな らないように, 事前に受替範囲の全体にわたって二 重管複相式注入工法による地盤改良を行っている.

表-2 に示すように, 撤去杭は直径 $\phi 800 \sim \phi 2,000$ の 計 53 本で, このうち防災センターのみが搪底杭と なっている. 受替杭は直径 $\phi 2,000 \sim \phi 2,200$ の計 3 7 本で, すべて拡底杭を採用している. 図-8〜図-11 は受替えの状況を示したものである.

\section{（2）実測值と予測值との比較およびその考察}

\section{a）建物と受替版の挙動}

図-12 と図-13 は JR 社宅 2 棟における応力導入時 の建物と受替版の変位挙動を示したものである. 図 中, 黒丸は実測値を, 白三角は従来の手法による予 測值を, 白菱形は複合ばねモデルによる予測值を表 している.ここで用いた従来の手法は, 杭の挙動を 評価するばねのばね定数を文献 10)に基づき算定し たものである. また, 上半のプラス側が建物各点の 隆起量を, 下半のマイナス側が受替版各点の沈下量 を示している.

これらの図から複合ばねモデルによる予測值は, 

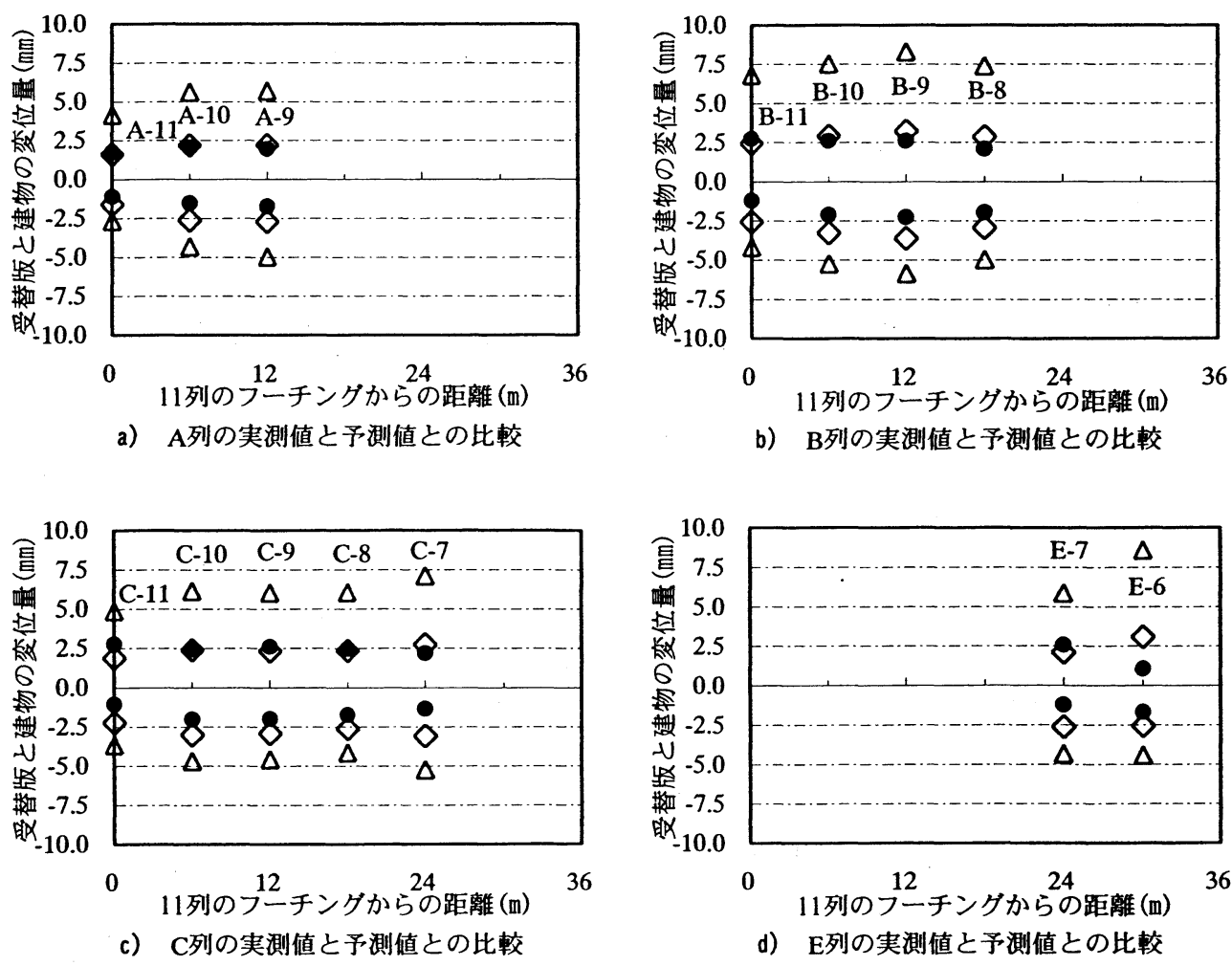

- 実測值予测值（従来モテル）

○予測值（複合ばねモデル）

図-12 JR 広町社宅 6 号棟における実測値と予測値との比較

従来の手法による予測值と比較して，実測值とより 良い一致を示していることがわかる. 図-12-d)に示 す E-6 点や図-13-b)に示す B-3 点における建物の変 位の予測值は，実測值と若干の相違があるが，これ は非受替部の影響によるものと考えられる。すなわ ち, 予測計算の対象範囲外にある建物の地中梁, 基 礎スラブおよび柱, 壁, 上部梁などの剛性の影響, あるいはその部分の基礎杭の周面摩擦などの影響が 他の点と比べ大きいため，当該点の変位が抑制され たものと思われる.これは建物のレベリングなどに 関連して，このような非受替部に隣接する箇所をジ ヤッキアップする必要が生じた場合には, 設計荷重 に対して十分な余力を持つジャッキを配置しておく ことが必要であることを示している.

図-14 は品川区防災センターの建物と受替版の挙 動を示したものである.この図から複合ばねモデル による予測值は, 従来の手法による予測値と比較し て，実測值をより良く説明していることがわかる.
しかしながら，建物の変位（図中，上半側に示す変 位）についてはあまり良い一致を示しておらず，こ れは防災センターの既設杭が拡底杭であることによ ると思われる．拡底杭は杭の先端部が下方に向かっ て広がるテーパー形状になっているため，杭に鉛直 上向きの荷重が作用した場合に，このテーパー部が 地盤に押し付けられる方向に挙動することが考えら れ, 実際の変位量が小さくなったものと考えられる.

式(11b)中の杭の形状を評価する係数 $I_{p}$ を, 予測 值と実測值が一致するように逆算すれば，本拡底杭 の場合には $I_{p}=6 \sim 7$ 程度になる. 形状係数 $I_{p}$ は 杭の種別, 拡底部の形状, 周辺地盤の変形特性など の要因を考慮して決定されるべきであり，この結果 を他の工事にそのまま適用することはできない. し かしながら，複合ばねモデルによる予測值は，実測 値と同様の変位の分布形状になること，その值は従 来の手法と比較してより良い一致を示すことなどか ら, 杭間の相対変位が特に重要である非受替部の近 


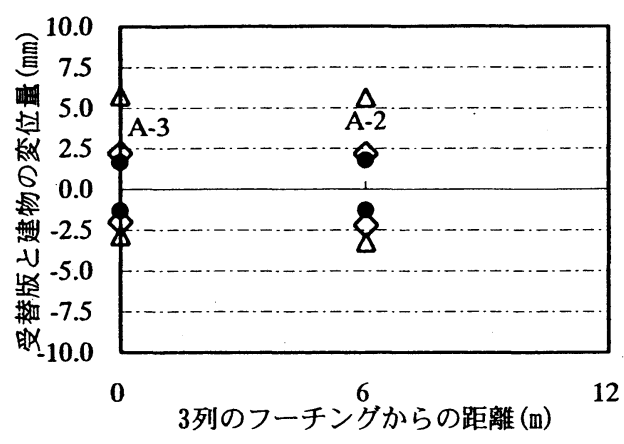

a) A列の実測値と予测値との比較

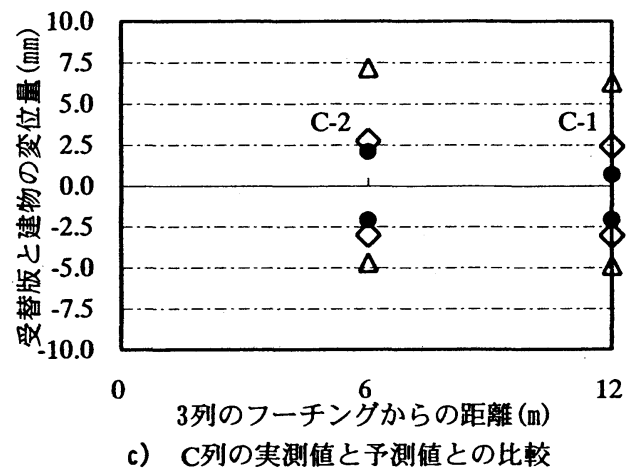

-実測値 、予測値（従来モデル）

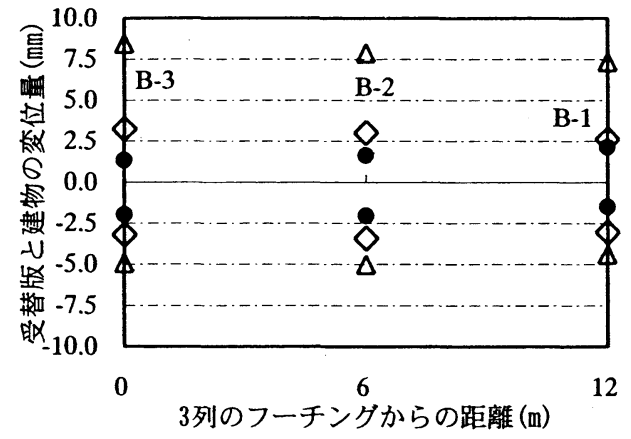

b) B列の実測値と予測値との比較

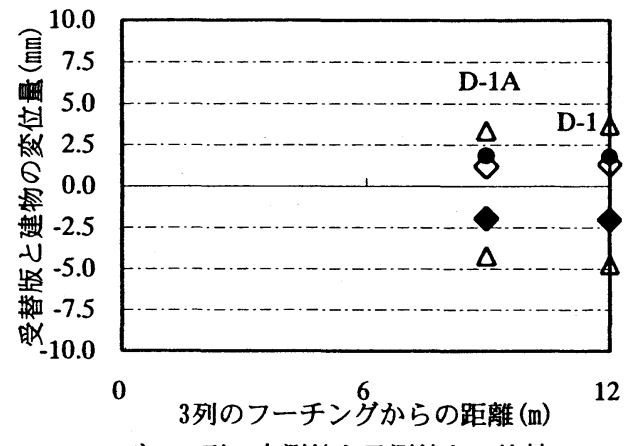

d） D列の実測値と予测値との比較

○予测値（複合ばねモテル）

図-13 JR 広町社宅 3 号棟における実測值と予測值との比較

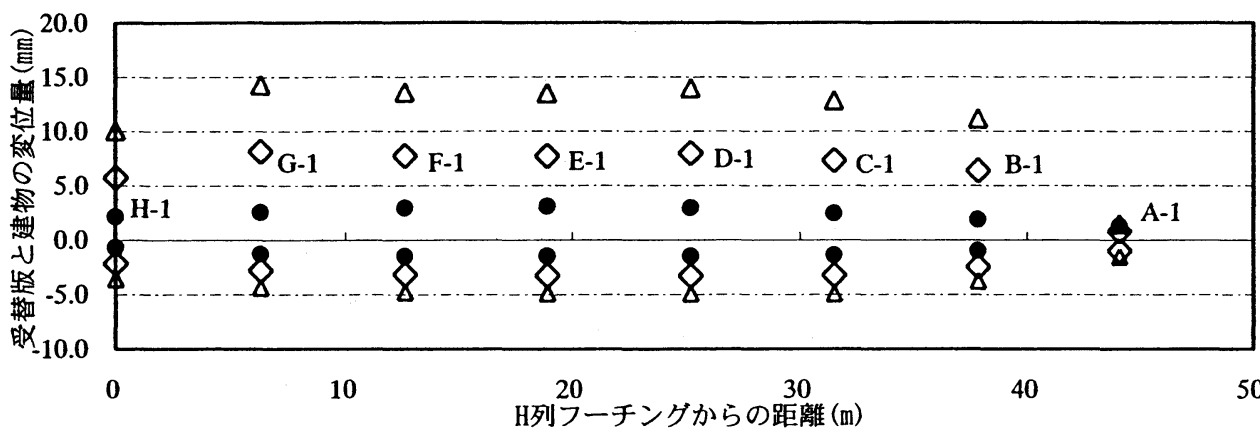

-実測値

$\Delta$ 予剆値（従来モデル）

○予測值（複合ばねモデル）

図-14 品川区防災センターにおける実測値と予測値との比較

傍においても，建物の健全性の照査に十分適用可能 であると思われる.

\section{b）複合ばねモデルの適合性の定量評価}

複合ばねモデルによる予測值は, 実測値と適合性 が良いことがわかった. また, 建物の変位は, 非受
替部の近傍において，建物本体の剛性の影響を受け る可能性が示された.ここでは非受替部からの位置 を指標にして, 複合ばねモデルの適合性を定量的に 評価することを試みる．以下に適合性を評価するた めの手法を述べる. 


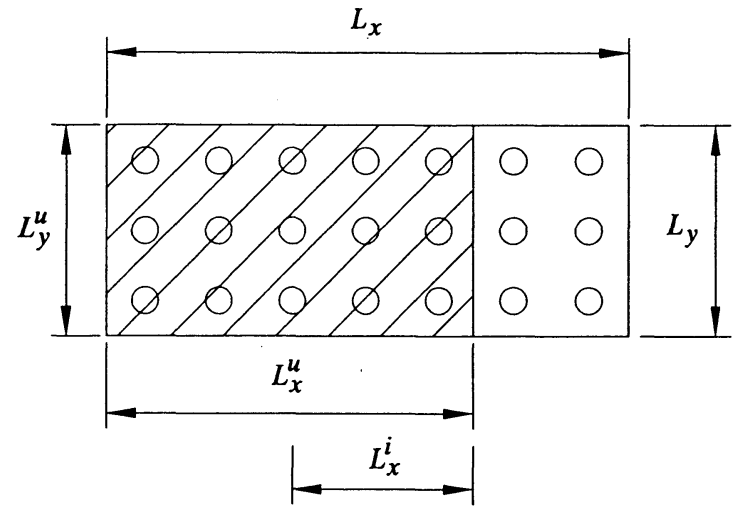

図-15 解析モテルの定量評価に用いた非受替部からの 位置を無次元化した指標

建物各点の変位の実測値と予測值をそれぞれ $m_{i}$, $a_{i}$ とし, また, 非受替部からの距離が同一な計測点 の総数を $N$ とすると, 受替部全体にわたる実測值と 予測値との平均的な差は式(12)で表される. 式(12) 中の $S^{2}$ を便宜上分散と呼び，この分散 $S^{2}$ の值が小さ いものほど適合性が高いと判断することにした.

$$
S^{2}=\frac{1}{N} \sum_{i=1}^{N}\left(m_{i}-a_{i}\right)^{2}
$$

なお, 品川区防災センターの計測点は, すべて非 受替部からの距離が同一なため,ここでは除外して いる.また，非受替部の位置は式(13)により無次元 化したものを指標にしている（図-15 参照).

$$
\frac{L_{x}^{u} \cdot L_{y}^{u}}{L_{x} \cdot L_{y}} \times \frac{L_{x}^{i}}{L_{x}^{u}}
$$

ここに

$L_{x}, L_{y}:$ 建物全体の幅と奥行きの長さ $(\mathrm{m})$

$L_{x}^{u}, L_{y}^{u}:$ 受替部の幅と奥行きの長さ $(\mathrm{m})$

$L_{x}^{i}:$ 非受替部から計測点までの距離(m)

である.

図-16 に従来の手法による予測值と複合ばねモテ ルによる予測值とを比較した結果を示す．この図か ら複合ばねモデルによる予測值は, 従来の予測手法 による予測值と比較して, 定量的にみて実測値との 適合性が高いことがわかる．また，非受替部からの 無次元化した位置が 0.2 以内の範囲では, 分散が大 きくなっている．すなわち，予測精度が低下してい ることがわかる.

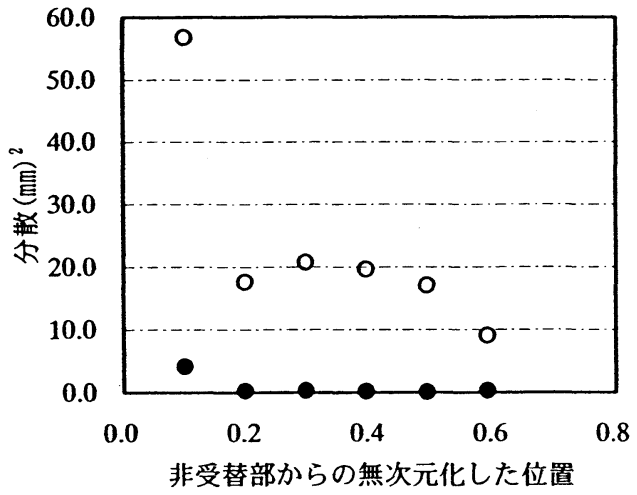

a) JR社宅 6 号棟の場合

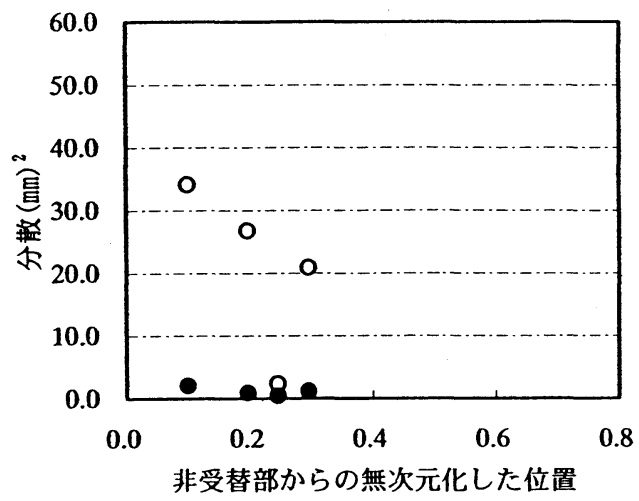

b) JR社宅 3 号棟の場合

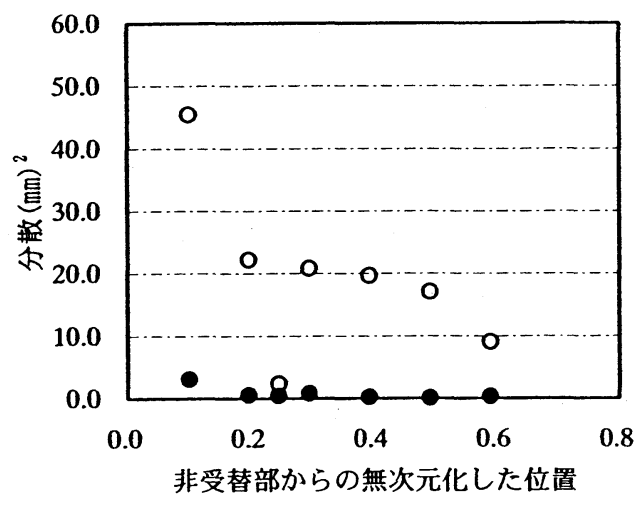

c） 2 棟を合計した場合

○従来モテル

・複合ばねモテル

図-16 解析モデルの定量評価

アンダーピニング工事の挙動予測において, 必要 となる精度は受替えの対象である既設構造物の種類 やその重要度などにより異なる. JR 社宅 6 号棟を例 にすれば，杭間の相対変位で $4.20 \mathrm{~mm}$, 杭の絶対変 


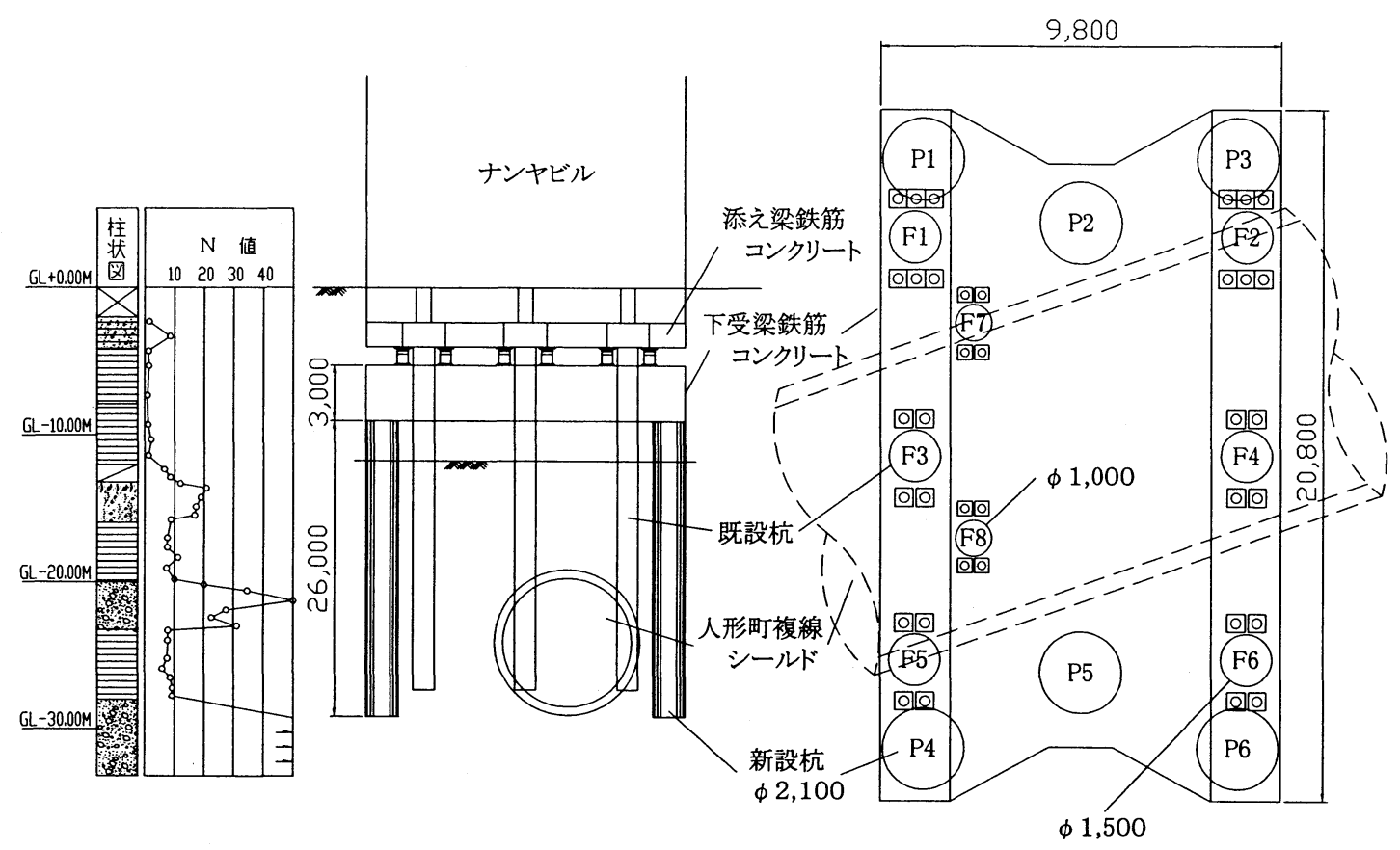

図-17 ナンヤビルの受替状況

位で $10.00 \mathrm{~mm}$ の 1 次管理值に対して, 従来の手法に よる予測值は平均 $4.18 \mathrm{~mm}$ の誤差を, 複合ばねモデ ルによる予測值は平均 $0.48 \mathrm{~mm}$ の誤差を生じている ことが図-12 よりわかる. 隣接する杭部の予測值が 互いに危険側の值となるケースを想定すれば，本工 事の場合, 最低でも $2.00 \mathrm{~mm}$ 程度以内の予測精度が 必要と思われる. また, 筆者らは想定外の要因に対 する安全性を考慮すれば, $1.00 \mathrm{~mm}$ 程度以内の誤差 で予測できるのが望ましいと考える.これらのこと から, 最小の 1 次管理値の $20 \%$ 程度以内の誤差で予 測できる手法が必要と考えている.

\section{（3）周辺部が複雑な互層地盤となっているアンダ ーピニングエ事例への複合ばねモデの適用 性の検討}

以上の結果より複合ばねモデルは， 2 層もしくは 3 層程度の首状地盤において適用性を有することが わかった. 次に, より複雑な地盤条件下におけるア ンダーピニングを対象に変位挙動の予測を行い, 互 層地盤においても複合ばねモデルが適用できるか否 かに検討を加えることとした. 複合ばねモデル中の 相互作用ばねは Mindlin 解に基づいて算定される. すでに述べたように Mindlin 解は半無限弾性地盤を 対象にしているため, これを互層地盤にそのまま適 用することはできない，そこでこの検討事例では式 (5)に示したような分散荷重による弾性解の和から
評価することにした.

\section{a） アンダーピニングエ事の概要 ${ }^{18)}$}

対象とした検証事例は, 昭和 60 年に施工された 営団地下鉄 11 号線人形町工区におけるナンヤビル のアンダーピニング工事である. ナンヤビルは SRC 造 8 階建の構造物であり, 計 10 本の場所打ち杭 ( $\phi$ $1,500=8$ 本, $\phi 1,000=2$ 本)により支持されている. 建物の総重量は $31 \mathrm{MN}$ でこのうち $26.3 \mathrm{M}$ を受替える ものである (図-17 参照).

土質は杭頭部から $4.5 \mathrm{~m}$ 程度が軟弱な地層であり, $\mathrm{N}$ 值が $0 \sim 1$ 程度の細砂と砂混じりシルトの互首が 分布している. その下には $\mathrm{N}$ 值 8 の粘土層が $8.0 \mathrm{~m}$ 程度, さらに $\mathrm{N}$ 值 30 の細砂層が $3.0 \mathrm{~m}$ 程度, そして $\mathrm{N}$ 值 10 の粘土層が $5.0 \mathrm{~m}$ 程度分布している.

\section{b) 実測値と予測值との比較およびその考察}

図-18 にナンヤビルにおける応力導入時の建物と 受替版の変位挙動の実測值と予測值とを示す．この 図をみると, 複合ばねモデルによる予測值は, 従来 の手法による予測値と比較して実測值と良い一致を 示していることがわかる.

図-19はナンヤビルとJR社宅 6 号棟の場合の分散 $S^{2}$ を比較したものである. 図中の横軸は受替版端部 からの距離を表しているが, ナンヤビルのアンダー ピニングは非受替部が存在しないため, それには工 学的な意味はない. また, JR 社宅 6 号棟については, 非受替部の影響を受けている範囲は除外して示した. 


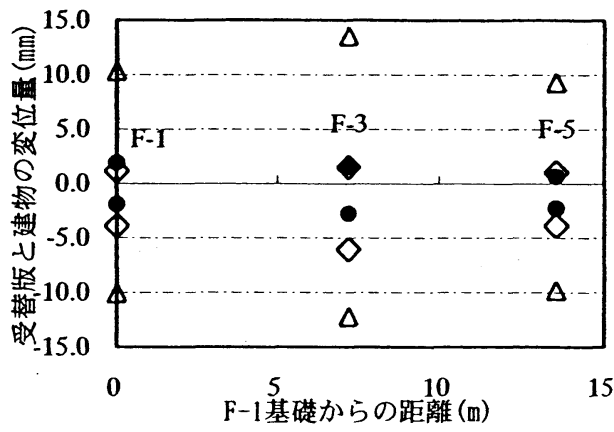

a) F1〜F5通りの実测値と予测値の比較

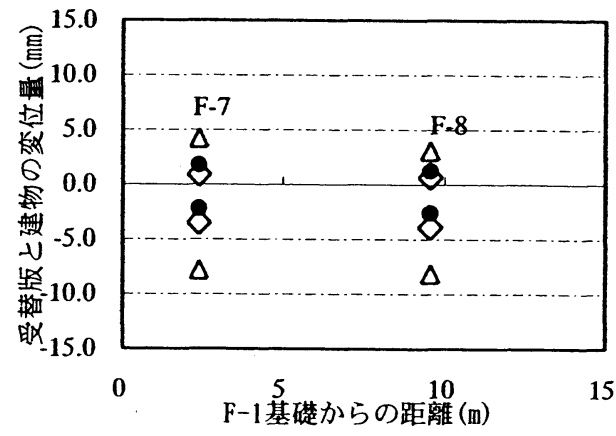

b) F7〜F8通りの実测値と予测值の比較

-実測値

$\Delta$ 予测值（従来モテル）

○予测値（複合ばねモテル）

図-18 ナンヤビルにおける実測値と予測値との比較

この図から, ナンヤビルの変位挙動の予測値は, $\mathrm{JR}$ 社宅 6 号棟のそれと比較して分散の幅が大きく, 推定精度が落ちることがわかる. しかしながら，分 散の平方根 $S$ は, 平均で $0.60 \mathrm{~mm}$ であり受替えの規 模や杭のスパンなどを併せて考えれば，実用上の予 測精度は十分高いと考えられ，本研究で提示した複 合ばねモデルが互層地盤におけるアンダーピニング 工事にも適用できることがわかる.

\section{5.まとめ}

本研究で得られた知見をまとめると以下のとお りである.

(1)アンダーピニング時の構造物の変位挙動の予 測において, 従来の手法に比べて本研究で提案 した複合ばねモデルを用いる手法は，変位の実 測值をより良く説明することが定量的に確かめ られた.したがって，先行応力導入が必要にな るような複雑な施行条件下のアンダーピニング においても，より合理的な受替えの制御が可能

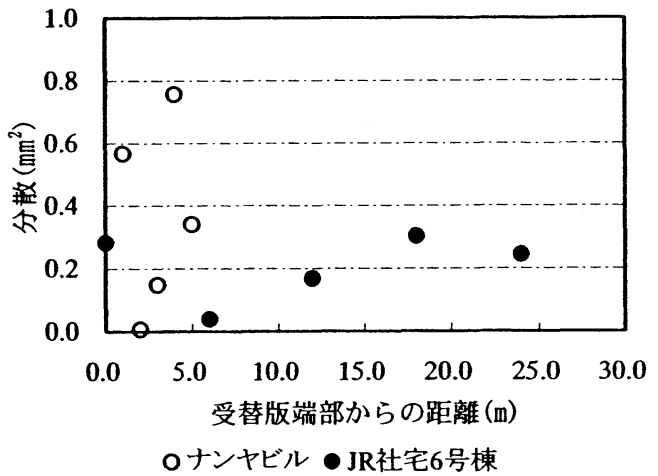

図-19 ナンヤビルと JR 社宅 6 号棟の建物変位の予測 値の分散 $S^{2}$ の比較

となり，工期短縮によるコスト縮減が期待でき る.

(2)拡底杭により支持される構造物をアンダーピ ニングする場合, 複合ばねモデルによる変位の 予測計算は実測の変位と同様のモードの解を与 えることから，建物の安全性の照查が可能であ る. しかしながら，拡底杭の拡底部の影響につ いては，今後さらに検討を加える必要がある.

(3)建物の一部分を受替えるアンダーピニングに おいて，建物の鉛直方向の変位は非受替部の影 響を受けて予測値よりも小さくなる.

\section{6.おわりに}

最近のアンダーピニング工事の傾向を見ると，受 替構造物の多様化や大規模化あるいは周辺環境の変 化に伴い，その施工条件がより複雑かつ厳しいもの になっているように思われる。

施工の側面から見れば，建物の供用を維持するの は当然のことだが，建物自体の老朽化や非受替部へ の荷重伝播などの要因を考えると，変位の管理基準 值は，いわゆる許容値と比較して相当に小さく設定 する必要がある。

また経済性の側面から見れば，世相を反映したコ ストの縮減は重要な命題である. しかし，建物下の 空頭制限や既設杭の大径化がますます狭险な空間で の施工を余儀なくさせることから，工種単位でのコ ストの縮減は難しく，本研究で示したような工期短 縮によるトータルコストの縮減などの手段を講じる 必要性が増加するものと思われる。

このような状況下において, アンダーピニングの 
変位挙動の予測手法の確立とその体系化は急務であ り，迅速かつ適正な受替制御や合理的なジャッキの 選定などに関してそれが重要な位置を占めることは 明らかである．また，その予測手法は汎用性が高く 簡易なものが望ましい. 地中構造物の断面力の算定 によく用いられるはり-ばね系モデルによる方法は, 本研究で示したように, 非対称な荷重系に対しても 断面力および変位の算定が容易にできることから， 有効な手段の 1 つであると思われる. 現場における 実測値との比較結果を見ると, 本研究で提案したよ うな簡易なモデルでも実用範囲内では十分に適用性 を有しているものと考えている. アンダーピニング の挙動予測は群杭の挙動（通常の群杭問題は杭がす ベて同一の方向に挙動するが，アンダーピニングの 場合は鉛直上向きと下向きの 2 つに分かれる）をど のように評価するかが重要である. また, 杭と地盤 との相互作用は, 杭の種別, 杭径, 杭の出来形, 周 辺地盤の特性などの様々な要因の影響を受ける. 多 くの現場計測結果との照合を行うことによって，よ り合理的な変位挙動の予測手法が確立されるものと 思われる.

謝辞 : 本研究をまとめるにあたり, 貴重な御意見を いただいた金沢工業大学環境系土木工学科木村定雄 助教授，佐藤工業(侏中央技術研究所小林恒一氏，同 首都圈業務部岡村直利氏, 挙動予測の計算に助力い ただいた同土木本部設計部門寺田武彦氏，また施工 当初から多くの御指導を賜った日本鉄道建設公団東 京支社の皆様に深く御礼申し上げる次第です.

\section{参考文献}

1) 例えば, 小泉淳: 大深度地下利用に関する技術的課題, 土木学会論文集, No.588/VI -38, 技術展望, pp.1-20,1998.3.

2）例えば，小西譲司 : アンダーピニング最近の傾向，基 礎工, 総説, pp.11-18,1986.11.

3）例えば, 山田昇, 清治均, 斎木公同良 : アンダーピニ ング支持構造物の挙動について-予測とその結果-, 第 55 回土木学会年次学術講演会講演概要集, VI-259, 2000.9 .

4) 例えば, 西林聖武, 矢萩秀一 : 高層ビル群のアンダー ピニング,トンネルと地下, 第 21,巻 3 号,pp.7-16,1990.3.
5) 例えば, 林二郎, 西村尚武, 松尾節夫, 小山浩史 : 片 福連絡線南森町工事における地下鉄のアンダーピニ ング工事での設計と実際，基礎工，pp.86-94,1996.3.

6) 猪瀬二郎, 小西諒司, 中村兵次 : 杭基礎で支持された 建物のアンダーピニング時の挙動について, 土木学会 論文集, No.435/VI-15, pp.43-50,1991.9.

7) 岡村直利: 都市土木における工期短縮の取組み(前編), 東京どぼく技士会, 第 11 号, pp.12-16,1998.11.

8) 岡村直利: 都市土木における工期短縮の取組み(後編), 東京どぼ技士会，第 12 号, pp.16-21,1998.12.

9）日本建築学会 : 建築基礎構造設計指針, pp.130-154, 1997.8.

10) 土木学会 : 国鉄建造物設計標準解説, 基礎構造物抗土 圧構造物, pp.182-183,1986.3.

11）山局邦男, 八尾真太郎 : マサツ群杭基礎の沈下に関す る理論解について, 第 9 回土質工学研究発表会講演集, pp.481-484,1974.

12) 山本春行, 冨永晃司, 山肩邦男 : 杭の相互作用問題に おける地中変位の評価法, 構造工学論文集, vol32B, pp.29-38,1986.3.

13）平山英喜 : 群杭基礎のミンドリン解に基づく地盤内応 力分布とその簡便法, 第 29 回土質工学研究発表会講 演集, pp.1445-1448,1994.6.

14) 例えば, Geddes.J.D : Stress in foudation soils due to vertical subsurface loading, Geotechnique, No.16, No.3, pp.231-255,1966.

15) 木村定雄, 小泉淳 : 地盤と覆工の相互作用を考慮した シールドトンネルの設計法について, 土木学会論文集, No.624/III-47, pp.123-134,1999.6.

16) 富田浩士, 東宗則, 松本直樹 : アンダーピニングの施 工計画, 第 55 回土木学会年次学術講演会講演概要集, VI-261, 2000.9.

17) 寺田武彦, 諏訪内幹男, 岡村直利 : アンダーピニング 支持構造物の挙動について-計測結果-, 第 55 回土木学 会年次学術講演会講演概要集，VI-260，2000.9.

18) 帝都高速度交通営団: 東京地下鉄道半蔵門線建設史 （渋谷～水天宮前)，pp.524-530, 1999.3

(2001. 6. 6 受付) 


\section{STUDY OF BEHAVIOR FORECAST-MODEL FOR UNDERPINNING OF PILE FOUNDATION STRUCTURE}

\section{Michiaki ICHINO, Yukinori SHIMIZU and Atsushi KOIZUMI}

Forecasting of structure behavior of the underpinning is carried out generally using simple settlement calculation for pile foundations. In actuality, there is not good congruence between forecast values and actual measured values. This cause originates in the interaction between behaviors of existing piles and those of new ones through the ground being disregarded. This paper evaluates the interaction of the existing and new piles, proposing a complex spring model that can explain the behaviors during the underpinning work. It also clarifies the suitability of this structural model by making comparisons of site measurement values. 